\title{
The Rise and Fall of Fear of Abuse in Consumer Bankruptcy: Most Recent Comparative Evidence from Europe and Beyond
}

\author{
Jason J. Kilborn*
}

Abstract: Prepared for a symposium celebrating the groundbreaking career of Jay Westbrook, this Article examines recent evidence of fear of abuse of the benefits of consumer bankruptcy and the gradual abatement of that fear in modern consumer insolvency law reform. It marshals evidence of a recent and accelerating retreat in both the judicial discretion that Westbrook attributed to lawmakers' fear of abuse and other more direct techniques to avoid abusive recourse to consumer discharge. Fear of abuse appears to be diminishing with accumulated experience as indicated by recent liberalizing reforms in Denmark, Slovakia, Poland, Austria, Russia, and Romania. At the same time, evidence from countries that have only begun to develop policies on personal insolvency and discharge-Croatia, Bulgaria, China, and Saudi Arabia - indicate that fear, or at least resistance to discharge relief, clearly persists.

Law is fundamentally a social science. Its theories usually can and should be tested based not just on the behavior of appellate courts but also on anthropological evidence of the actual frontline form and effect of law's regulation of human behavior. Jay Westbrook has led the charge in an enormously fruitful campaign of discovery of such evidence in the United States. ${ }^{1}$ Our federalist legal system offers a natural laboratory for comparison of different approaches and outcomes in a checkerboard of state and federal districts and their various actors' often widely divergent approaches to key issues. This is surprisingly true even in the supposedly unified federal

\footnotetext{
* Professor of Law, John Marshall Law School (Chicago) and Van der Grinten Professor of International \& Comparative Insolvency Law, Business \& Law Research Centre, Radboud University (Nijmegen, The Netherlands), jkilborn@jmls.edu.

1. See, e.g., Teresa A. Sullivan, Elizabeth Warren \& Jay Lawrence Westbrook, As We Forgive Our DeBTORS: BANKRUPTCY AND CONSUMER CREDIT IN AMERICA 17-20 (1989) (describing the methodology behind the authors' Consumer Bankruptcy Project, a study of debtors in ten federal judicial districts across the United States); TERESA A. Sullivan, Elizabeth WARREN \& JAY LAWRENCE WeStBroOK, THE Fragile MidDle Class: AMERICANS IN DEBT $7-$ 11 (2000) (discussing Phase II of the Consumer Bankruptcy Project, which focused on debtors in sixteen federal districts); Teresa A. Sullivan, Elizabeth Warren \& Jay Lawrence Westbrook, Consumer Debtors Ten Years Later: A Financial Comparison of Consumer Bankrupts 1981-1991, 68 AM. BANKR. L.J. 121, 122-24 (1994) (same).
} 
consumer bankruptcy system. Opportunities for comparative analysis are supercharged, however, when one moves outside the United States and beyond the Anglo-American context on which most consumer bankruptcy scholarship has focused.

Almost exactly twenty years ago, Jay extrapolated his research on U.S. consumer bankruptcy to the new frontier of emerging consumer insolvency systems in Europe. In so doing, he launched a field of scholarship that would yield rich rewards. Before the turn of the twenty-first century, there was all but nothing in Europe to compare with Anglo-American consumer bankruptcy practice. ${ }^{2}$ By the late 1990 s, however, the first consumer discharge procedures were emerging in Northern Europe and had produced a foundation of operational results for comparison. Jay was among the first Americans to seize this new opportunity.

In a short commentary on one of the earliest comparative consumer bankruptcy conferences in Europe, Jay noted the potential of comparative perspectives on the topic. ${ }^{3}$ At that time, he was studying judicial discretion and a resulting pernicious phenomenon that he referred to as "local legal culture," marked by persistent disparate treatment of similarly situated consumer debtors across the United States. ${ }^{4}$ The comparative conference offered Jay a chance to extrapolate his U.S. findings to the few emerging consumer discharge regimes in Europe and to develop hypotheses as to the causes of the phenomenon of local legal culture. He noted that even the sparse European data revealed the emergence of local legal culture as a consequence of judicial discretion, particularly in determining (1) whether certain debtors should have access to a discharge and (2) the duration of the payment plan imposed on debtors as a quid pro quo for earning discharge relief. ${ }^{5}$

In light of his U.S. research, augmented by this limited set of comparative observations, Jay tentatively suggested a cause for the discretion producing these local legal culture disparities on both sides of the Atlantic: he attributed this syndrome to a powerful fear of abuse by debtors of the benefit of consumer discharge relief, a benefit that was radical and revolutionary in Europe and still somewhat controversial in the United

2. When U.S. reformers were looking for comparative ideas for revision of the U.S. bankruptcy law in the 1970s, they concluded "the bankruptcy experience of other countries is not a useful resource.” COMM'N ON THE BANKR. LAWS OF THE U.S., REPORT OF THE COMMISSION ON THE BANKRUPTCY LAWS OF THE UNITED STATES, H.R. DOC. NO. 93-137, at 66 (1973).

3. Jay Lawrence Westbrook, Local Legal Culture and the Fear of Abuse, 6 AM. BANKR. INST. L. REV. 25, 33-34 (1998).

4. See Teresa A. Sullivan, Elizabeth Warren \& Jay Lawrence Westbrook, The Persistence of Local Legal Culture: Twenty Years of Evidence from the Federal Bankruptcy Courts, 17 HARV. J.L. \& PUB. POL'Y 801, 803-07 (1994) (applying the concept of local legal culture to bankruptcy law); Westbrook, supra note 3, at 26-27 (elaborating upon the concept of local legal culture).

5. Westbrook, supra note 3, at 25, 32-33. 
States. ${ }^{6}$ He optimistically predicted "[f]urther research over the next several years in the various countries that have adopted these new laws could yield a rich harvest of new evidence and perhaps unexpected variations."

This commentary was published just as I was beginning my academic career, and it inspired everything I have done since then. It is extremely gratifying to be able to celebrate Jay's career in this symposium issue by adducing recent comparative evidence in support of his thesis in that early commentary and by providing a small taste of the "rich harvest of new evidence" from the most recent developments in consumer bankruptcy in Europe and beyond. As Jay predicted, European authorities have been extremely concerned about debtors abusing the new discharge regimes, and common impediments to relief have been far more obvious and imposing than the nuanced effects of discretion and the resulting local legal culture. Twenty years after Jay identified this fear of abuse, however, a thaw is manifest in the icy European attitude, as evidenced in particular by developments over just the past few months. Fear of abuse-and discretionary or statutory mechanisms for making the path to discharge narrower and more onerous - appears to be diminishing with time and experience. This message needs to be broadcast more effectively, as several projects for new consumer discharge laws reveal a resurgence of fear of abuse or at least reticence to embrace the notion of discharge relief. Thus, the vicious cycle repeats itself.

This Article presents the most recent evidence of these propositions in three segments. Part I discusses three regimes that exemplify the trends discussed above - that is, extremely fearful, highly discretionary procedures that abruptly reversed course on fear of abuse after a decade or two of operation but retained significant court discretion (Denmark, Slovakia, Poland). Part II announces some of the most recent developments, including notable harbingers of both a softening of fear of abuse and a reining-in of discretion across Europe (Austria, Russia, Croatia, Romania). Part III looks to the future of several nascent personal insolvency regimes-in-waiting, which evidence a return to square one and a high degree of fear or resistance to discharge (Bulgaria, China, Saudi Arabia). Like Jay's commentary, mine here is designed primarily to stimulate interest in and discussions of developments of which many followers of English-language legal scholarship will be unaware ${ }^{9}$ but which hold great potential for revealing

6. Id. at 28 .

7. Id. at $33-34$.

8. Id. at 34 .

9. See id. at 25-26 (noting that the value of the paper "will lie in stimulating discussion by referring the reader to a very interesting series of papers about consumer bankruptcy that many will not have read"). 
important cross-cultural trends about this important area of legal and social policy.

\section{From Fear and Discretion to Acceptance and Greater Standardization}

\section{A. Denmark 1984-2005}

The first story is a bit dated, but it is both closely connected to Jay's early foray into comparative consumer bankruptcy and perfectly revealing of the trend away from the discretion and fear he described. Denmark was the bellwether, adopting the very first consumer "debt adjustment"10 law in Europe in 1984. ${ }^{11}$ The Danish law was structured very much like the Norwegian law that caught Jay's interest, ${ }^{12}$ as a persistent problem of local legal culture plagued Danish practice for two decades and led to the only major reform of this law in 2005. This syndrome of local legal culture resulting from judicial discretion was fairly clearly born of a powerful fear of abuse of this radical departure from the traditional pacta sunt servanda notion that debts must be paid. Trailblazing Danish lawmakers were expressly hesitant to undermine individual-payment morality, so they imposed strict, discretionary access controls at both the entry and exit points to discharge relief.

Simply to gain access to the relief process, debtors had to clear two hurdles. First, they had to exhibit "qualified insolvency," which implied a clear and doubt-free inability to regain financial footing in the foreseeable future, by reducing profligate living standards and redoubling efforts to service debts in full. ${ }^{13}$ Second, as in Norway, ${ }^{14}$ each court had to be convinced that offering relief in any particular case was subjectively appropriate in light of a series of enumerated factors, such as the debtor's efforts to manage debt problems and the makeup of the debt load (preferably relatively few fines, penalties, and "irresponsible" debts, such as debts for luxury consumption). ${ }^{15}$ Predictably, the highly subjective and probing inquiries prompted by these two tests produced widely and persistently divergent results among debtors

10. This is the usual language used to name these laws in continental Europe, eschewing both the stigma and the suggestion of an easy way out implicit in the word "bankruptcy."

11. Lov nr. 187 af 09.05.1984 om gældssaneringslov [Law No. 187 of 9 May 1984 on consumer debt adjustment], af konkurslov afsnit IV, kapitel 25-29 [at Bankruptcy Act Section IV, Chapters 25-29] (Den.) [hereinafter Konkurslov].

12. See Westbrook, supra note 3, at 32-33 (discussing the discretionary elements of Norwegian bankruptcy law, which produced local variations similar to those observed in the United States).

13. Konkurslov, supra note $11, \S 197$.

14. See Westbrook, supra note 3 , at 32 (discussing the Norwegian law's requirement that the debtor's bankruptcy be "permanent in nature").

15. Jason J. Kilborn, Twenty-Five Years of Consumer Bankruptcy in Continental Europe: Internalizing Negative Externalities and Humanizing Justice in Denmark, 18 INT'L INSOLVENCY REV. 155,168 (2009). 
based on little more than the location of the governing court. In 2002, for example, while the court in Odense admitted approximately $66 \%$ of its 161 debt adjustment applications, "the court in Roskilde admitted only $39 \%$ of its 139 applicants, and the court in Copenhagen admitted a mere $25 \%$ of [its] 828 applications." ${ }^{16}$ For debtors who navigated past this Scylla, the Charybdis of court confirmation of debtors' five-year debt adjustment plans presented an equally daunting and equally divergent challenge. While the court in Århus closed $41 \%$ of its 244 cases with a confirmed plan, "the courts in Ålborg and Randers confirmed plans in only $19 \%$ and $15 \%$, respectively, of the 136 cases closed" by each of these courts, and "[a]s in most years, the Copenhagen court had a miserly success rate of only $13 \%$ of its 8,689 closed cases." $" 17$

For the few lucky debtors who cleared these two procedural hurdles, more local legal cultural variation plagued their pursuit of earned relief. Like the Norwegian law that Jay learned about, ${ }^{18}$ the Danish law also left completely to court discretion the terms of debtors' payment plans to earn their discharge - both the length in years and the budget allocated to debtors for family support. ${ }^{19}$ Unlike in Norway, the Danish courts quickly coalesced around a standard five-year term, but courts differed widely in their assessment of proper budgets to support, as the statute directed, a "modest" lifestyle. Some courts allowed supplementary budget items beyond a basic allowance (for things like eye and dental care and household appliance rental), while others did not. ${ }^{20}$ Even the amount of the basic budget allowance varied widely and was not based on variances in local cost of living, as this allocation varied by $40 \%-50 \%$ among otherwise similar districts. ${ }^{21}$ These varying perspectives on appropriate sacrifice and thrift led some debt counselors to suggest that their pre-bankruptcy clients engage in in-country bankruptcy tourism, moving what we would now call their "center of main

16. Id. at $174-75$.

17. Id. at 175 .

18. See Westbrook, supra note 3, at 33 (discussing the Norwegian courts' discretion regarding payment plans).

19. See Kilborn, supra note 15, at 172, 177 (stating that Danish law originally left questions of disposable income and plan length "open to individual case-by-case and court-by-court discretion" and that budgetary practices "varied widely" among local courts).

20. Kilborn, supra note 15, at 177.

21. See Betænkning nr. 1449 af august 2004 om gældssanering [Report No. 1449 of August 2004 on Debt Settlement] 144 (Den.) (reporting that in 1997-1998, budget allowances for singles varied from 2,500 kr. to $3,500 \mathrm{kr}$. and for couples from 4,000 kr. to 6,000 kr.); Dommerfuldmægtigforeningen \& Advokatrådet, Redegørelse Vedrørende Andringer $i$ Konkurslovens Bestemmelser om Goeldssanering [Statement Regarding Changes to the Bankruptcy Act's Debt Settlement Provisions] 34 (1999) (Den.) (same). 
interest" (i.e., their home residence) from a miserly region to a more generous (reasonable?) region. ${ }^{22}$

After nearly twenty years of frustration with these overly restrictive and divergent court demands, the Danish government stepped back from fear of abuse and launched a reform process that culminated in 2005 . While the reform did not deal directly with the regional variations in admission and plan confirmation rates, it relaxed access criteria and standardized plan terms.

In a technical but crucial about-face, the initial presumption of restricted access was reversed. That is, while debtors were originally presumed not admissible unless the court was convinced that the totality of the circumstances militated in favor of relief, after 2005 the presumption is in favor of admission unless consideration of a slightly reformulated list of factors "suggests decisively against" relief. ${ }^{23}$ Also, at least for former smallbusiness entrepreneurs, the "qualified insolvency" test was modified expressly to provide admission for debtors whose economic situation is "unclear," 24 and the payment term for a discharge plan for these former smallbusiness entrepreneurs was set by Justice Ministry regulation at three years, rather than the standard five years for consumers. ${ }^{25}$

For all debtors, the reform dealt head-on with the local legal cultural problem of vast differences in court parsimony in discharge plans. The Justice Ministry was tasked with establishing uniform, nationwide basic budgetary allowances, and the Ministry took a much more humane approach to debtor support. The new budget guidelines exceeded the upper range then applied by the courts in most debt adjustment cases by nearly $20 \%$, and additional types of income were exempted entirely from distribution to creditors, such as state transfer payments for children. ${ }^{26}$

As Jay predicted, however, local legal culture is quite sticky. The Danish courts have continued their rigorous watch at the gates into and out of the discharge procedure. In the decade following the reform, fewer than half of all petitions for admission to the personal discharge procedure were granted (fewer than $40 \%$ in 2009 and 2010). ${ }^{27}$ While the reasons for these rejections are not reported, anecdotes from other jurisdictions suggest that most of the

22. Kilborn, supra note 15, at 174.

23. Konkurslov, supra note 11, §§ 197(4), 231a(4).

24. Id. $\S \S 231 \mathrm{~b}, 236 \mathrm{a}(2)$.

25. Bekendtgørelse nr. 894 af 22.9.2005 om gældssanering [Executive Order No. 894 of 22 September 2005 on Debt Settlement] § 2 (Den.).

26. Kilborn, supra note 15 at 1, 176-78.

27. See Danmarks Domstole, Statistik for Skiftesager M.V.: Modtagne SAGER om INSOLVENSSKIFTE M.V., http://www.domstol.dk/om/talogfakta/statistik/Documents/Skiftesager/ [https://perma.cc/F6HX-JUNN] (reporting the number of debt adjustment applications received and the number of debt adjustment applications declined). Calculations were based on ten years of data from 2006 to 2016 (on file with author). 
rejected applications involve paperwork errors rather than merit-based judgments. Of an average of just over 5,000 cases closed per year during this period, only about $30 \%$ (an average of about 1,680) concluded with an approved plan. Though again looking on the bright side, excluding the cases rejected at the entryway, this represents a $70 \%$ confirmation rate for admitted cases. $^{28}$

\section{B. Slovakia 2006-2017}

When Jay attended the comparative conference in 1997, Denmark's personal discharge regime and similar ones in neighboring Scandinavia were effectively the only games in town. ${ }^{29}$ Since then, the dam has broken and new consumer discharge laws and experience have flooded into virtually every country in Europe, ${ }^{30}$ often through multiple iterations and amendments of new laws. ${ }^{31}$ Much of the intervening experience has been analyzed elsewhere, ${ }^{32}$ so this paper will focus on the very latest developments.

The most exciting and bold departure from a system historically both quite discretionary and quite fearful of abuse occurred in Slovakia, whose consumer discharge system was entirely overhauled effective March 1, $2017 .^{33}$ This amendment was preceded by a long period of disappointment with the original quite restrictive law. The Slovak consumer discharge provisions were added to the Law on Bankruptcy and Restructuring 2005 with a delayed effective date of January $1,2006 .{ }^{34}$

28. Kilborn, supra note 15, at 173.

29. See Westbrook, supra note 3 , at 31 . Though Jay notes emerging systems in France and Germany as well, in 1997 the French law offered no discharge to consumers and the German consumer bankruptcy reforms would not become effective until 1999. See JASON J. KILBORN, EXPERT RECOMMENDATIONS AND THE EVOLUTION OF EUROPEAN BEST PRACTICES FOR THE TREATMENT OF OVERINDEBTEDNESS, 1984-2010, at 13 n.69, 14 (2011).

30. But see discussion infra subpart III(A) (addressing Bulgaria's hesitance to adopt consumer debt discharge procedures).

31. See, e.g., Gerard McCormack et al., Study on a New Approach to Business FAILURE AND INSOLVENCY: COMPARATIVE LEgAL ANALYSIS OF THE MEMBER STATES' RELEVANT PROVISIONS AND PRACTICES 333-48 (2016) (reviewing the variations among consumer discharge laws in EU member states).

32. See generally, e.g., KILBORN, supra note 29 (tracing the evolution of consumer bankruptcy systems throughout Europe); WORLD BANK, REPORT ON THE TREATMENT OF THE INSOLVENCY OF NATURAL PERSONS (2013) (discussing laws of insolvency of natural persons throughout the world).

33. See Radovan Pala \& Michal Michalek, Long-Awaited Changes to Restructuring Rules in Slovakia, TAYLOR WESSING LLP (Feb. 1, 2017), https://united-kingdom.taylorwessing.com/en /insights/rcr-update/long-awaited-changes-to-restructuring-rules-in-slovakia [https://perma .cc/FH6E-G8DF] (discussing the enactment of an amendment to Slovakia's bankruptcy law).

34. Zákon, č. 7/2005 Z.z. o konkurze a reštrukturalizácii a o zmene a doplnení niektorých zákonov z 9. decembra 2004 [Law on Bankruptcy and Restructuring and on Amendment and Supplementation of Several Other Laws of 9 December 2004] (Slovk.), http://ec.europa.eu/internal _market/finances/docs/actionplan/transposition/slovakia/d7.3-ml-sk.pdf [https://perma.cc/UN5BVXKB]. 
A surprisingly imposing barrier to relief prevented all but a few cases from making their way past the admissions stage for the first decade of this new law. To access relief, debtors had to pay the equivalent of about $\$ 800$ (€663.88) in filing and trustee fees and demonstrate that they had assets to liquidate that would produce the equivalent of about $\$ 2,000(€ 1,659.70)$ in distributions for creditors. ${ }^{35}$ Debtors who cleared this hurdle faced yet another: like most European consumer insolvency laws, the Slovak regime required debtors to earn their fresh start by complying with a three-year payment plan imposed by the court. ${ }^{36}$ The amount of payment demanded of debtors was subject to the all-but-unfettered discretion of the court, guided only by a frightening suggestion that the payment obligation could be "up to $70 \%$ of the debtor's net income." 37

Few debtors managed to clear the entry barrier to this new system, though those who did so seem largely to have succeeded in obtaining relief. It took seven years of operation for this new procedure to produce 100 cases admitted to the three-year payment plan phase, though 484 debtors had applied for such relief and only about 200 cases were fully administered (leaving a significant and persistent backlog). ${ }^{38}$ By the end of 2016, the total number of discharge applications over the ten-year life of the regime had risen to 1,855, with administered cases still lagging far behind at 685 , of which 478 had been admitted to the payment plan phase. ${ }^{39}$ This methodical approach to case evaluation was apparently fairly successful, as only a handful of cases over the eleven-year life of this original procedure ended in default or withdrawal, and most admitted cases seem to have concluded with a granted discharge about three years later, suggesting that courts had exercised their discretion in imposing relatively judicious payment obligations. ${ }^{40}$

Digging a bit deeper reveals a stark local legal culture issue at the admissions stage. The admissions figures just mentioned produce an admissions rate of 70\% of all administered cases from 2006 through 2016.

35. Id. § 171(1) (repealed Mar. 1, 2017); Vladimír Kordoš \& Filip Takáč, Resurrection of Personal Insolvencies in Slovakia?, EUROFENIX, Spring 2017, at 34.

36. Kordoš \& Takáč, supra note 35 , at 34.

37. Id.

38. These figures derive from annual bankruptcy case statistics published by the Slovak Ministry of Justice. See Konkurzné konania na okresných súdoch SR, MiNISTERSTVO SPRAVODLIVOSTI SLOVENSKEJ REPUBLIKY (Slovk.), http://www.justice.gov.sk/Stranky

/Informacie/Statistika-konkurznych-konani-OS.aspx [https://perma.cc/5J5Q-772X] [hereinafter Slovak Bankruptcy Statistics] (reporting discharge application and administration statistics in Slovakia from 2006 through 2012).

39. See id. (reporting discharge application and administration statistics in Slovakia from 2006 through 2016). 2016).

40. See id. (compiling bankruptcy proceeding outcome statistics in Slovakia from 2006 through 
But in examining district-level rates among the eight districts adjudicating these cases, stark differences emerge. In the last six years of the original regime, the court in the capital region of Bratislava admitted $100 \%$ of administered cases, with the high-volume courts in Banská Bystrica and Žilina not far behind. The district court in Trenčín, in contrast, admitted only $33 \%$ of administered cases during this period (fewer than $20 \%$ before 2015). ${ }^{41}$ The small number of cases makes these figures less compelling, but the differing admissions practices of these decision makers seem to fairly clearly reflect very different attitudes toward, most likely, quite similar debtors. Payment-plan practices likely also differed dramatically. Over the entire eleven-year period under the original law, only two debtors emerged with a discharge from the process in Trenčín, compared with five in Bratislava and thirty-eight in Banská Bystrica (percentages are difficult to determine here, but judging by any perspective, the ratios of success vary wildly across districts). ${ }^{42}$

The Slovak government set out in 2016 to rectify this sad situation and align Slovak practice with regimes that are more accommodating to debtors. The legislature quickly took up and adopted the Justice Ministry's bold revision of the bankruptcy law in November 2016, effective March 1, 2017.43 Departing from the European standard and all but abandoning fear of abuse, the new Slovak regime offers debtors a free choice between asset liquidation and immediate discharge or a five-year payment plan, ${ }^{44}$ parallel to the U.S. choice between chapters 7 and 13 of the Bankruptcy Code. Debtors must be represented by the publicly supported Centre for Legal Aid, ${ }^{45}$ and the now reduced $€ 500$ application fee can be lent by the Centre (for repayment in installments over three years) to debtors unable to pay the fee immediately. ${ }^{46}$ To make liquidation an even more attractive option, the range of debtors' property exempt from liquidation has been expanded with a homestead exemption of $€ 10,000$ in unencumbered value in a home. ${ }^{47}$

41. See id. (providing discharge application and administration statistics by district from 2011 through 2016).

42. See id. (reporting discharge statistics by district from 2006 through 2016).

43. See Kordoš \& Takáč, supra note 35 , at 34 (describing the implications of the amendment).

44. Zákon, č. 7/2005 Z.z. o konkurze a reštrukturalizácii a o zmene a doplnení niektorých zákonov [Law on Bankruptcy and Restructuring and on Amendment and Supplementation of Several Other Laws] (Slovk.), https://www.noveaspi.sk/products/lawText/1/59304/1/2 [https://perma.cc/WKK2-D6D6] (current version).

45. Id. $\S 166 \mathrm{k}$.

46. Centrum PRÁvnej POMOci, OsobnÝ BANKRot 4-5 (2017) (Slovk.), $\mathrm{http}: / /$ www.centrumpravnejpomoci.sk/wp-content/uploads/2014/03/Bro\%C5\%BE\%C3\%BAraOB-02_2017.pdf [https://perma.cc/NFR3-4WHV].

47. Zákon, č. $7 / 2005$, supra note $44, \S 167 \mathrm{~h}(4)$. The Justice Ministry issued a press release on the new law and homestead exemption. Dostupnejši osobný bankrot, MiNISTERSTVO SPRAVODLIVOSTI SLOVENSKEJ REPUBLIKY (Mar. 1, 2017) (Slovk.), http://www.justice.gov.sk /Stranky/aktualitadetail.aspx?announcementID=2179 [https://perma.cc/XK7U-3L7G]. 
In stark contrast with recent U.S. practice, Slovak lawmakers embedded in their new system a clear preference for quick liquidation-and-discharge relief, actively discouraging debtors from pursuing the payment plan route. For debtors who choose to preserve their nonexempt assets and propose a payment plan, the reserved budget for family support must cover the debtor's family's housing and basic needs (still undefined in the $l a w^{48}$ ) and offer creditors a minimum 30\% dividend (and at least 10\% more value than a liquidation would produce).$^{49}$ For debtors whose disposable income does not appear sufficient to meet these thresholds, the statute directs the trustee to recommend that the debtor file a petition for bankruptcy liquidation. ${ }^{50}$

By the end of November 2017, the Centre for Legal Aid had registered nearly 63,000 consultations with debtors interested in the new discharge procedure. ${ }^{51}$ Over 8,000 petitions were filed in the first nine months of availability of the new processes, 7,800 seeking liquidation and discharge, and slightly more than 200 proposing a five-year payment plan. ${ }^{52}$ The courts quickly accelerated their formerly languid administration process, granting admission to 6,454 bankruptcy cases and 117 payment plan cases.$^{53}$ Of these, about half of the bankruptcy cases have already closed with a discharge, while a payment plan has been confirmed in forty cases. ${ }^{54}$ In the nine months from March to November 2017, the number of petitions for bankruptcy exceeded the entire number filed in the eleven-year period of the old law by a factor of four. The number of cases admitted in the first nine months of the new procedure was 13.5 times as large as the total number admitted over the previous ten years, and 17 times as as many discharges have been granted. ${ }^{55}$ The new Slovak system is a unique example of the modern European retreat from fear of abuse and embrace of standardized, low-burden personal discharge.

48. See Silvia Belovičová, New Personal Insolvency Regime in Slovakia, 0-1-CEE! CENT. EUR. LEgal News \& VIEWS Blog (Dec. 16, 2016), http://www.ceelegalblog.com/2016/12/857/ [https://perma.cc/7MQ7-98WR] (noting that debtor living expenses are to be determined by trustees and courts, "and let's hope they will use their discretion wisely").

49. Zákon, č. $7 / 2005$, supra note $44, \S 168 \mathrm{c}(4)-(5)$.

50. Id. $\S 168 \mathrm{c}(7)$.

51. Rok 2017 na ministerstve spravodlivosti, MinisterstVo SPRAVOdLIVOSTI SLOVENSKEJ REPUBLIKY (Dec. 19, 2017) (Slovk.), http://www.justice.gov.sk/Stranky/aktualitadetail.aspx ?announcementID=2285 [https://perma.cc/2YWG-NALA] [hereinafter 2017 at the Ministry of Justice].

52. Id.

53. Id.

54. Id.

55. See Slovak Bankruptcy Statistics, supra note 38 (reporting bankruptcy admission and discharge statistics in Slovakia from 2006 through 2016); 2017 at the Ministry of Justice, supra note 51 (reporting bankruptcy admission and discharge statistics from March through November of 2017). 


\section{Poland 2009-2015}

A somewhat similar story played out in Poland, though over a shorter period of time. Poland's first consumer discharge law was adopted much later than the Slovak version, and it ran into serious trouble immediately. Effective at the end of March 2009, ${ }^{56}$ the Polish Law on Bankruptcy and Rehabilitation was supplemented to allow consumers to seek discharge relief, but, again, fear of abuse compelled legislators to place two major obstacles in the way of access to this relief. First, debtors had to establish that their insolvency resulted from exceptional circumstances entirely beyond their control. ${ }^{57}$ As if this were not sufficient to bar access to all but a small handful of applicants, admission also required a demonstration of sufficient assets to cover the costs of administration, which varied from case to case and were estimated at between $€ 1,000$ and $€ 5,000.58$

In the nearly four years from March 2009 through the end of 2012, just over 2,160 consumer debtors applied for discharge relief under the new law, but only sixty (2.8\%) were admitted into the system. ${ }^{59}$ The Justice Ministry was not pleased. The Ministry proposed a reform, expressing its feeling that these statistics "and legislative experiences of other countries show, the current restrictive approach envisaged in Polish law should be liberalized." 60 A little over a year later, a bill was on the floor of the legislature with an explanatory statement reminding lawmakers of the many benefits of consumer discharge law, observing that the Polish approach had failed due to the cost and qualification barriers noted above and aiming to "reduce or completely remove" these barriers. ${ }^{61}$ The bill traveled through the legislative process quickly, and legislators put fear of abuse behind them as they passed the liberalizing amendments into law at the end of August 2014, effective December 31, 2014. ${ }^{62}$ Meanwhile, statistics on the operation of the old law came to an ignominious end, with a total of 2,735 applications submitted over

56. Marek Porzycki \& Anna Rachwał, Consumer Insolvency Proceedings in Poland 5 (Instytut Allerhanda, Working Paper 12/2015, 2015).

57. Prawo upadłościowe [Bankruptcy and Reorganization Law] (2003 r. Dz. U. Nr 175, poz. 1361), Art. I (Pol.); Katarzyna Kołodziejczyk, Consumer Bankruptcy in Poland, MONEY MATTERS, no. 14, 2017, at 20, 20.

58. Kołodziejczyk, supra note 57, at 20.

59. See Ewidencja spraw upadlościowych (w tym upadlości konsumenckiej "of”) za lata 20052015, INFORMATOR STATYSTYCZNY WYMIARU SPRAWIEDLIWOŚCI (Pol.), https://isws.ms.gov .pl/pl/baza-statystyczna/opracowania-wieloletnie/download,2853,56.html [https://perma.cc/GAN4-WSXM] (reporting bankruptcy applications and admissions in Poland from 2009 through 2012).

60. Ministerstwo SPRAWIEdLIWŚCI, REKOMENDACJE ZESPOlU Ministra SPRAWIEDLIWOŚCI DS. NOWELIZACJI PRAWA UPADŁOŚCIOWEGO I NAPRAWCZEGO 270 (2012) (Pol.) (original in Polish).

61. O zmianie ustawy - Prawo upadłościowe i naprawcze oraz niektórych innych ustaw [Bill Amending the Bankruptcy and Reorganization Law] (2014 Nr 2265) (Pol.) (original in Polish).

62. Porzycki \& Rachwał, supra note 56, at 5. 
nearly six years and only 120 successfully admitted - an ultimate aggregate admission rate of just $4.4 \%{ }^{63}$

From 2015 forward, Polish debtors have been free to seek discharge relief so long as they did not cause their insolvency "intentionally or as a result of gross negligence. ${ }^{\prime 64}$ For debtors with limited assets, administration costs are initially covered by the state treasury (and the costly formality of publication of case information in newspapers was scrapped in favor of electronic publication to reduce expense). ${ }^{65}$ After liquidation of the debtor's assets, Polish practice still follows the European norm of imposing a payment plan on debtors to earn their discharge, but both the term (up to three years, down from five in the earlier law) and payment amount are still left to unfettered court discretion. ${ }^{66}$ In a powerful move away from fear of abuse, however, the law explicitly recognizes that many debtors will lack payment capacity beyond meeting their basic needs, so it provides for an immediate discharge if the court finds that this is "clearly shown." ${ }^{67}$ For cases where a payment plan is imposed, it can be amended for improvements in the debtor's payment capacity, but only for "reasons other than an increase in remuneration for work or services personally performed by the debtor." 68 This provides a creative incentive for debtors to maximize their productivity immediately following insolvency proceedings.

As in Slovakia, Polish debtors eagerly accepted the invitation to this newly liberalized relief. Already in the first year of the new Polish law, more than 5,600 debtors applied and 2,153 were admitted — nearly twenty times as many admitted cases as in the previous six years combined. ${ }^{69}$ Those figures nearly doubled again in 2016, with almost 8,700 applications and 4,447 admission orders, and the acceptance rate rose above $50 \%$ for the first time. ${ }^{70}$ Many applications are still being rejected, but largely for incorrect completion of the forms, ${ }^{71}$ and the average four-month processing time for cases suggests that the admission rate will rise as the crush of new cases

63. See Informator StATYSTYCZny Wymiaru SPRAWIEDLIWOŚCI, supra note 59 (presenting applications and admission statistics from 2009 through 2014).

64. O zmianie ustawy - Prawo upadłościowe i naprawcze, ustawy o Krajowym Rejestrze Sądowym oraz ustawy o kosztach sądowych w sprawach cywilnych [Amendment to the Bankruptcy and Reorganization Law] (2014 r. DZ. U. poz. 1306), Art. 4914(1) (Pol.) [hereinafter Prawo upadłościowe] (original in Polish).

65. Id., Art. $491^{7}(1)$, Art. $491^{16}(2)$; Porzycki \& Rachwał, supra note 56, at 10, 29.

66. Prawo upadłościowe, supra note 64 , Art. $491^{14}$, Art. $491^{15}$.

67. Id. at Art. $491^{16}$ (1) (original in Polish).

68. Id. at 64 , Art. $491^{19}$ (3) (original in Polish).

69. See INFORMATOR STATYSTYCZNY WYMIARU SPRAWIEDLIWOŚCI, supra note 59 (providing applications and admission statistics from 2009 through 2016).

70. Id. Admissions levelled off in 2017 at just over 5,500, though with a sharp turn upward in the last three months of the year. 2017 upadlość konsumencka, CENTRALNY OŚRODEK INFORMACJI GOSPODARCZEJ, http://www.coig.com.pl/2017-upadlosc-konsumencka-lista_osob .php [https://perma.cc/SR3D-WPAU].

71. INFORMATOR STATYSTYCZNY WYMIARU SPRAWIEDLIWOŚCI, supra note 59. 
makes its way through the procedure. Fear of abuse is in definite retreat in Poland.

\section{Most Recent Developments: Less Discretion, Less Fear of Abuse}

\section{A. Russia 2015-2017}

Only two years old, the new Russian consumer bankruptcy system has already encountered and addressed the same cost impediments that hindered the operation of the Slovak and Polish systems. It also confronted an unexpected form of resistance when lower courts creatively interpreted the new law to prohibit use by most consumer debtors. Here again, in a decisive rejection of fear of abuse, the Russian Supreme Court last year put the system back on track to achieve its primarily rehabilitative purposes.

In the transition back to a market-based economic system following decades of stagnation under Communism, Russia adopted a consumer bankruptcy law in December 2014, with a delayed effective date of October 1, 2015. ${ }^{72}$ This law carried few of the hallmarks of fear of abuse seen elsewhere. Though it appears to follow European standards by requiring debtors to relinquish both nonexempt asset value and some amount of future income, the income expropriation period seems to last only six months, and debtors are entitled to a nondiscretionary exemption of a statutorily determined portion of their income. ${ }^{73}$ So far so good.

The ironic problem, as in Slovakia and Poland, seems to be money, as debtors have struggled to afford the costs of the procedure. In the first year of the law, of an estimated avalanche of 670,000 potential overindebted applicants, only 33,000 debtors petitioned for relief, only 14,800 cases were opened, and fewer than 500 made their way completely through the complex, ten-month-long average procedure. ${ }^{74}$ Lawmakers first thought cost barriers were keeping the sea of applicants back, so in November 2016 they reduced the filing fee from 6,000 rubles to a nominal 300 rubles (from about $\$ 244$ to $\$ 12$ at Purchasing Power Parity exchange rate (PPP)), effective January 1, $2017 .{ }^{75}$ But by the end of the second year of the new law's operation, the total

72. Jason J. Kilborn, Treating the New European Disease of Consumer Debt in a PostCommunist State: The Groundbreaking New Russian Personal Insolvency Law, 41 BROOK. J. INT'L L. 655,686 (2016).

73. Id. at 698-700, 710-11.

74. Nataliīa Shvabauèr, Zhizn' vzămy, Ros. GAz. (Nov. 7, 2016) (Russ.), https://rg.ru /2016/11/07/sredi-rossijskih-grazhdan-okazalos-bankrotov-bolshe-chem-sredi-kompanij.html [https://perma.cc/47DW-PL7X].

75. Georgiū Panin, Kakie vazhnye zakony vstupiat v silu s 2017 goda, RoS. GAZ. (Dec. 28, 2016) (Russ.), https://rg.ru/2016/12/28/kakie-vazhnye-zakony-vstupiat-v-silu-s-2017 -goda.html [https://perma.cc/2YEA-JQTA]. 
number of consumer cases commenced had little more than doubled to just over $40,000 .^{76}$

The reduction in filing fees was merely a drop in the bucket compared to the real problem: the cost of the required "financial administrator," set by statute at 25,000 rubles (about $\$ 1,000$ at PPP) but in reality often higher, and other administrative expenses reportedly boost the total cost of a personal bankruptcy filing to at least 100,000 rubles in Moscow (\$4,000 PPP) and at least 60,000 rubles in provincial regions (about $\$ 2,500$ PPP). ${ }^{77}$ This is in addition to the logistical challenge of filing a bankruptcy case in the often distant commercial courts, only one of which is located in each "subject" (governmental region) of Russia's expansive territory. ${ }^{78}$

Both the cost factor and another less obvious obstacle to relief were revealed as serious doctrinal problems when one of the first cases under the new law made its way to the Russian Supreme Court. ${ }^{79}$ Two months after the effective date of the new law, the Commercial (Arbitrazh) Court in the remote Western Siberian Tyumen Oblast opened a personal bankruptcy case only to close it five months later on two grounds, both related to the absence of any substantial asset value in the case. ${ }^{80}$ First, the court felt that the absence of sufficient asset value to offer even a partial distribution to unsecured creditors undermined the very purpose, in its view, of the bankruptcy law - that is, to offer proportionate satisfaction of creditors' claims from the debtor's assets. ${ }^{81}$ Second, insufficient asset value to pay administrative costs constitutes a basis for case closure under Article 57 of the Law on Insolvency, and the court held that funds could not be advanced by a nondebtor to cover these costs. ${ }^{82}$

The Supreme Court struck back at these philosophical constraints on the new law and dealt another blow to fear of abuse of consumer discharge. Consumer bankruptcy has other purposes, the Court asserted, beyond satisfying creditors. Access to legislatively prescribed relief cannot be restricted simply on the basis that the debtor has no asset value to offer creditors, and this cannot be equated to "bad faith," more specific evidence

76. Tat'iana Zamakhia, Dobrosovestnym grazhdanam predlozhili spisat' dolgi, Ros. GAZ. (Nov. 8, 2017) (Russ.), https://rg.ru/2017/11/08/dobrosovestnym-grazhdanam-predlozhili-spisatdolgi.html [https://perma.cc/LVG2-P67P].

77. Tat'iana Zykova, Bol'she ne dolzhen, Ros. GAZ. (Jan. 12, 2017) (Russ.), https://rg.ru/2017/01/12/chislo-bankrotov-v-rossii-za-poslednie-3-mesiaca-vyroslo-na-27.html [https://perma.cc/8RL9-VG29].

78. Kilborn, supra note 72, at 691-93.

79. Opredelenie Verkhovny̌ Sud Rossiǔskoĭ Federatsii ot 23 iavara 2017 [Decision of the Russian Federation Supreme Court of Jan. 23, 2017], N. 304-ĖS16-14541, Delo N. A7014095/2015. 2017 (Russ.).

80. Id. at 2-3.

81. Id. at 2 .

82. Id. 
of which is required to deny a discharge. ${ }^{83}$ And while debtors must, indeed, somehow cover the administrative costs of the proceeding (which at the time were much smaller than now, with only a 10,000 ruble fee for the financial administrator), the Court pointed out that the law contained no provision forbidding debtors from seeking help from third parties in covering these fees. ${ }^{84}$

For debtors without generous friends, the law does indeed still require full payment of administrative costs ${ }^{85}$ which clearly remains a deterrent for many debtors, as it was in Slovakia and Poland. Fortunately, the Ministry of Economic Development has already proposed a simplification of the procedure - mainly exclusion of the costly financial administrator - for cases involving debtors with limited debts and assets (less than 900,000 rubles of debt, about $\$ 37,000$ at PPP, fewer than ten creditors, and income less than the statutory minimum livable income). ${ }^{86}$ This further step away from fear of abuse has been met with some resistance, so this will be a developing story to watch in 2018 and beyond. Incidentally, lawmakers in neighboring Ukraine have long agitated for a personal bankruptcy law as well, but to date, they have not progressed beyond the stage of a draft bill, the most notable of which has been pending for two years. ${ }^{87}$

\section{B. Austria 1995-2017}

Perhaps the biggest change ushered in at the start of the new year is a major withdrawal from fear of abuse at the culmination of a long-fought battle in Austria. This is one of the small handful of consumer discharge regimes that was already in operation beginning in 1995, before Jay wrote his commentary, and it exemplifies the fear of abuse that he discerned in Europe at the time. For over twenty years, the Austrian procedure imposed three classic European hurdles to deter feared abuse by consumer debtors. After decades of criticism by counseling centers and other observers, ${ }^{88}$ each

83. Id. at 3 (original in Russian).

84. Id. at 4 .

85. Federal'nyı̌ Zakon o Nesostoiatel'nosti (Bankrotstve) [Federal Law on Insolvency (Bankruptcy)], N 127-FZ. st. 57(1) (Russ.); see also Zykova, supra note 77 (noting that the administrator can request case closure at any point if his fees and expenses are not paid by the debtor).

86. Elena Berezina \& Irina Zhandarova, Vernut' vse, Ros. GAZ. (Mar. 13, 2017) (Russ.), https://rg.ru/2017/03/13/grazhdanam-uprostiat-bankrotstva.html [https://perma.cc/ZV55-Z7HH]; Zykova, supra note 77.

87. Natal'ia Mytskovskaia, Kak stat' bankrotom: novyr zakon mozhet pomoch' yzbavyt'sia ot nevyplachennykh dolhov, KOMSOMOL'SKAIA PRAVDA V UKRAYNE (Nov. 15, 2017) (Ukr.), https:// kp.ua/print/economics/592146-kak-stat-bankrotom-novyi-zakon-mozhet-pomoch-yzbavytsia-otnevyplachennykh-dolhov [https://perma.cc/K28J-M8A5].

88. E.g., ASB Schuldnerberatungen, SchuldenRePort 2016 14, 18 (2016) (Austria) (calling for overdue reforms in Austrian insolvency law); Christiane Moser, Österreich: Reform des 
of these three obstacles was cleared away by near-unanimous legislative reform effective November 1, 2017. ${ }^{89}$

First, like in Poland and Russia, the Austrian law originally required debtors to pay at least the administrative costs of the proceeding. For those unable to do so immediately upon applying for relief, such debtors had to comply with another prerequisite: a mandatory attempt to work out their debt problems privately through an out-of-court negotiation with creditors. ${ }^{90}$ This negotiation was, unsurprisingly, very seldom successful, so in the reform it was finally scrapped. ${ }^{91}$ Austria thus joins Sweden in having abandoned mandatory debt counseling and negotiation as a prerequisite for formal consumer insolvency relief. ${ }^{92}$

Second, like virtually every European consumer discharge regime, the Austrian procedure requires both a liquidation of nonexempt assets and a payment plan. Historically, most such plans were accepted by a vote of creditors. Debtors had to propose to pay creditors an amount equal to five years' worth of their projected nonexempt income, and they could string out those payments over as many as seven years to lighten the burden. ${ }^{93}$ Such a plan is accepted by an affirmative vote of creditors who represent a majority in number and amount of the claims of all voting creditors. ${ }^{94}$ While the great majority $(70 \%)$ of Austrian personal insolvency cases in the past have concluded with such a court-mediated payment plan, ${ }^{95}$ low-income debtors have been largely shut out of the process by the unique final minimumpayment hurdle discussed below. With the reform to allow low-income debtors realistic access to relief, the necessity to propose a payment plan for creditor voting has now been limited to debtors with substantial nonexempt

Privatkonkurses überfällig, DAS BUDGET, no. 78, 2016, at 6, 6 (Austria) (noting that Austria is lagging behind in private bankruptcy reform).

89. Clemens Mitterlehner \& Christa Kerschbaummayr, Reform of Personal Bankruptcy Procedure in Austria, MONEY MATTERS, no. 15, 2017, at 8, 8.

90. KonKuRSORDNUNGS-NOVELlE 1993 [BANKRUPTCY AMENDMENT OF 1993] BUNDESGESETZBLATT [BGBL] No. 974/1993, § 183(2) (Austria), https://www.ris.bka .gv.at/Dokumente/BgblPdf/1993_974_0/1993_974_0.pdf [https://perma.cc/B79C-HTTF].

91. Philipp Wetter, Austria: Major Changes in Personal Bankruptcy Law, SCHOENHERR (July 4, 2017), https://www.schoenherr.eu/si/publications/publication-detail/austria-major -changes-in-personal-bankruptcy-law/ [https://perma.cc/32US-3T5X].

92. Jason J. Kilborn, Out with the New, In with the Old: As Sweden Aggressively Streamlines Its Consumer Bankruptcy System, Have U.S. Reformers Fallen Off the Learning Curve?, 80 AM. BANKR. L.J. 435, 458 (2006).

93. KONKURSORDNUNGS-NOVELLE 1993, supra note 90, §§ 193(1), 194(1).

94. INSOLVENZRECHTSÄNDERUNGSGESETZ 2010 [IRÄG 2010] [INSOLVENCY LAW AMENDMENT 2010] BunDESGESETZBLATT [BGBL] No. 29/2010, § 147(1) (Austria), https://www .ris.bka.gv.at/Dokumente/BgblAuth/BGBLA_2010_I_29/BGBLA_2010_I_29.html [https://perma.cc/3JXX-4ALX].

95. Georg Kodek, Handbuch Privatkonkurs: Die Sonderbestimmungen fur das INSOLVENZVERFAHREN NATÜRLICHER PERSONEN 384 tbl.C.3 (2015). 
income. That is, debtors with little or no nonexempt income can proceed immediately to the final stage, a court-imposed earned discharge period. ${ }^{96}$

This earned discharge period and its culmination were the subjects of the third and most substantial reform. Neither the length of this period nor the amounts demanded from debtors were ever subject to any notable degree of court discretion. Originally, debtors formally assigned to a trustee all of their actual income in excess of an objective statutory "existence minimum" amount for seven years. ${ }^{97}$ An additional requirement echoed the sentiment of the Russian Tyumen Oblast Court discussed above regarding the purpose of bankruptcy: at the conclusion of this seven-year period, Austrian debtors received a discharge only if they had paid off administrative costs and produced a dividend of $10 \%$ of unsecured creditors' claims.$^{98}$ Debtors who missed this mark only slightly could hope for a hardship discharge at court discretion, perhaps after an additional three-year period of toil and sacrifice, but the discharge could be and sometimes was denied to debtors who failed to produce a satisfactory dividend for creditors. ${ }^{99}$ Many more low-income debtors were doubtless deterred from even attempting to obtain discharge relief, knowing they likely could not cover costs and produce the minimum $10 \%$ dividend for creditors. ${ }^{100}$

As of November 1, 2017, in a tectonic shift from longtime fear to full acceptance of consumer discharge, Austrian legislators scrapped the 10\% minimum dividend, softened the requirement to cover administrative costs, and reduced the earned discharge period from seven to five years. ${ }^{101}$ At the conclusion of the now five-year period, the court enters a discharge regardless of whether the debtor has covered costs and produced a dividend for creditors. ${ }^{102}$ Administrative costs that cannot be covered by debtors are advanced from the state Treasury, to be collected from the proceeds of liquidation of debtors' nonexempt assets or collection of nonexempt income. ${ }^{103}$ If the debtor's asset value and five years of nonexempt payments

96. INSOLVENZRECHTSÄNDERUNGSGESETZ 2017 [IRÄG 2017] [INSOLVENCY LAW AMENDMENT 2017] BundesGeSETZBLATt [BGBL] No. 122/2017, §§ 193(1), 194(1) (Austria), https://www.ris.bka.gv.at/Dokumente/BgblAuth/BGBLA_2017_I_122/BGBLA_2017_I_122.html [https://perma.cc/LWF7-RPRE].

97. KONKURSORDNUNGS-NOVELLE 1993, supra note 90, § 199(2).

98. Id. $\S \S 194,213$.

99. Id.

100. See ASB SChULDNERBERATUNGEN, supra note 88, at 14-15 (discussing the $10 \%$ minimum); KODEK, supra note 95, at 165-202, 249-338.

101. INSOLVENZRECHTSÄNDERUNGSGESETZ 2017, supra note 96, §§ 199(2), 213(1).

102. Id. § 213(1).

103. InSOLVENZORDNUNG [INSOLVENCY CODE] BundESGESETZBLATt I [BGBL] no. 122/2017, as amended, § 184(1)-(2) (Austria) https://www.ris.bka.gv.at/GeltendeFassung.wxe ?Abfrage $=$ Bundesnormen $\&$ Gesetzesnummer $=10001736 \&$ Fassung Vom $=2017-10-31$ [https://perma.cc/WEG7-86U2]. 
have not managed to cover administrative costs, the debtor remains liable to cover those costs only "if and when he is in a position to do so without impairment of his [and his family's] necessary support."104 Even this obligation prescribes (i.e., is barred by a statutory limitations period) three years after the conclusion of the proceedings. ${ }^{105}$ The Czech Republic now stands alone in the European Union with a law that requires a minimum dividend to unsecured creditors (30\%) for consumer debtors to earn their discharge. ${ }^{106}$ Perhaps not enough time has passed for fear of abuse to abate since the Czech consumer discharge became available in 2008, but one hopes the Czech Republic will follow Austria's example in far less than the twentytwo years it took for Austria to do so.

\section{Croatia 2016, Romania 2018}

The two newest consumer discharge procedures in Europe reveal a bit of unfortunate backpedaling toward fear of abuse, though there is good reason to expect that discretion will be exercised sparingly and within relatively narrow boundaries in these two latecomer systems. Both will be unfolding stories to watch in the years to come.

1. Croatia.-Croatia was the most recent European Union Member State to adopt a consumer bankruptcy procedure, effective January 1, 2016. ${ }^{107}$ It immediately took two steps backward toward fear of abuse by adopting the prereform Austrian procedure, minus the minimum dividend to creditors. Not learning from the repeated failures of these processes in neighboring regions, Croatian legislators reimposed two futile access restrictions just abandoned by Austria, along with what seems like a fairly menacing multiyear payment obligation.

First, Croatian debtors can gain entry to the in-court discharge procedure only after engaging a counseling center to propose an out-of-court settlement plan to creditors. ${ }^{108}$ When the counseling center inevitably concludes that this effort is doomed to failure, it issues a certificate to that effect, which the debtor must present within three months with a petition for bankruptcy

104. Id. $\S 184(3)$.

105. Id.

106. KILBORN, supra note 29 , at $30,37$.

107. Zakon o stečaju potrošača [Law on Consumer Bankruptcy], NN 100/2015 (1936) (Croat.); Emir Bahtijarevic \& Ema Mendusic Skugor, New Insolvency Legislation to Thoroughly Change Bankruptcy Procedures in Croatia, CEE LegAl MATTERS, Feb. 2016, at 88, 88.

108. OzREN IVKović \& MARKo KRUC, SCHONHERR, CROATIA: CONSUMER BANKRUPTCY ACT INTRODUCES CONSUMER BANKRUPTCY INTO THE LEGAL SYSTEM (2016), https://www .schoenherr.eu/uploads/tx_news/Croatia_Consumer_Bankruptcy_final_pdf3.pdf [https://perma.cc/W45U-U3KL]. 
relief. ${ }^{109}$ The state agency that oversees these counselors, the Financial Agency (FINA), has released statistical data on the first two years of the new Croatian procedure indicating that a total of 1,159 debtors have engaged counseling centers to initiate the out-of-court process. ${ }^{110}$ These debtors had an average of only six creditors and mostly quite small debts, but in only one case were all creditors somehow convinced to sign onto the debtor's proposed settlement plan (and in only sixteen cases was an agreement reached even with some of the debtor's creditors). ${ }^{111}$ Certificates of failure had thus been issued to 795 debtors, with the same result most likely awaiting most or all of the remaining applicants. ${ }^{12}$

Second, to gain access to the formal discharge procedure, debtors must again present a settlement plan to creditors in an in-court process. Only after that effort inevitably fails again, a liquidation of the debtor's nonexempt assets ensues, and like in Austria, Croatian debtors are relegated to an additional "behaviour checking" period of between one and five years. ${ }^{113}$ While the law appears to leave the precise duration of this period to judicial discretion, it seems likely that courts will in most cases choose the maximum five-year term. This was the result in the very first personal bankruptcy case in Croatia, where a fifty-one-year-old former entrepreneur with no assets and only pension income was assigned a five-year term from which she filed an appeal for a reduction to a year and a half. ${ }^{114}$ During this period, debtors are subject to a nondiscretionary requirement of turnover of all income above the statutory exemption. The Croatian statutory minimum income figures seem far less livable than their Austrian equivalents, with one Croatian journalist characterizing them as "neoliberal euthanasia." 115 This likely explains why only a fraction of the expected 10,000-20,000 potential debtors have applied for relief. ${ }^{116}$ In this respect, the newest European consumer discharge system

109. Id.

110. Financijska agencija (Fina), PREgled ZBiRnih PODATAKa IZ Sustava PRovedbe STEČAJA POTROŠAČA ZA RAZDOBLJE OD 1.1.2016. DO 03.04.2018. GODINE 2 (2018) (Croat.), http:// www.fina.hr/lgs.axd?t=16\&id=19566 [https://perma.cc/J4YR-U2LM].

111. Id. at 2,7 .

112. Id. at 7.

113. IVKOVIĆ \& KRUC, supra note 108.

114. See Ljubica Gatarić, Prva u osobni bankrot otišla propala poduzetnica iz Krapine, VEČERNJI LIST (Oct. 17, 2016) (Croat.), https://www.vecernji.hr/vijesti/prva-u-osobni-bankrot -otisla-propala-poduzetnica-iz-krapine-1121543 [https://perma.cc/7FKP-QUE9] (reporting the details of Croatia's first personal bankruptcy case).

115. See Leo Buljan, Možete li preživjeti s 800 kuna mjesečno? Ako potpišete osobni stečaj, bolje da naučite!, PORTAL DNEVNO (June 26, 2014) (Croat.), http://www.dnevno.hr/novac/mozeteli-prezivjeti-s-800-kuna-mjesecno-ako-potpisete-osobni-stecaj-bolje-da-naucite-126174/ [https://perma.cc/APA5-RYJR] (original in Croatian) (citing minimum income figures of $\$ 133$ per month for the debtor, $\$ 80$ for an adult family member, and $\$ 53$ for each child (not at PPP)).

116. See IVKOVIĆ \& KRUC, supra note 108 ("According to the Ministry, somewhere between 10,000 and 20,000 of the indebted citizens might take advantage of this opportunity."). 
may reveal something of a resurgence of fear of abuse, though not in the guise of judicial discretion.

2. Romania.-Meanwhile, the latest European consumer discharge system to actually begin operations has just come online in Romania as of January 1,2018 . While the Romanian legislature unanimously adopted its Law no. $151 / 2015$ "on the insolvency procedure of natural persons" in June $2015,{ }^{117}$ the government pushed back the effective date several times. ${ }^{118}$ This delay was attributable in part to government efforts to constrain discretion in evaluating debtors' capacities to support settlement plans with creditors and to endure a multiyear earned discharge period.

The Romanian law adopts the French approach ${ }^{119}$ of routing debtors through standing insolvency commissions, which evaluate whether cases should be directed to a negotiation with creditors and a potential five-year payment plan, or, for debtors whose financial situation is "irremediably compromised," to a liquidation-and-discharge procedure. ${ }^{120}$ In performing the sensitive and critical evaluation of debtors' payment capacities that determines which path is pursued, the insolvency commissions are not left to their own devices; rather, the Ministry of Justice directed the chair of the central insolvency commission to publish detailed criteria for determining a "reasonable standard of living" for debtors in insolvency proceedings. These criteria must be based on a list of national economic benchmarks, including cost-of-living indices, various family and household compositions, and transportation and housing guidelines. ${ }^{121}$ The publication of these criteria seems to have been delayed as of this writing, but the effort to constrain discretion and contain fear of abuse is manifest.

If Romanian institutions embrace the French approach to the notion of "irremediably compromised" debtors (as seems highly likely), many if not most debtors will be routed to an immediate liquidation-and-discharge

117. Legii 151/2015 privind procedura insolvenței persoanelor fizice [Law on the Insolvency Procedure of Natural Persons] publicată în Monitorul Oficial al României, Partea I, nr. 464/26.06.2015 (Rom.); Mihaela Condrache \& Liviana Andreea Nimineț, Personal Bankruptcy and the Romanian Realities, STUD. \& SCI. RES., no. 22, 2015, at 7, 8.

118. See, e.g., Ordonanță de urgență pentru prorogarea termenului de intrare în vigoare a Legii nr. 151/2015 privind procedura insolvenței persoanelor fizice [Government Emergency Ordinance for the extension of the entry into force of Law no. 151/2015 on insolvency procedure of natural persons] publicată în Monitorul Oficial al României, Partea I, nr. 962/24.12.2015 (Rom.).

119. See KilbORN, supra note 29, at 34-35 (tracing the development of France's commissionbased approach to processing debtors' cases).

120. Condrache \& Nimineţ, supra note 117 , at 9-11.

121. Hotărâre 419/2017 pentru aprobarea Normelor metodologice de aplicare a Legii nr. 151/2015 privind procedura insolvenţei persoanelor fizice [Decision Approving Methodological Norms for the Application of Law on the Insolvency of Natural Persons] publicată în Monitorul Oficial al României, Partea I, nr. 436/13.06.2017, art. 2 (Rom.). 
procedure. ${ }^{122}$ The insolvency commissions can send particularly low-income, elderly debtors to simplified proceedings, which require a simple observation period of three years before a final discharge is granted. ${ }^{123}$ For all others, the asset liquidation is followed by a payment period, during which a courtdetermined proportion of the debtor's income in excess of reasonable living expenses must be paid to creditors. ${ }^{124}$ This proportion is determined in accordance with the published budgetary guidelines for a "reasonable standard of living." 125 The duration of the payment period is determined by the percentage of debts paid off - as little as one year if $50 \%$ of debts are paid within that time - but given the finances of most debtors, the most common objectively determined term will be five years for debtors unable to produce at least a $40 \%$ dividend. ${ }^{126}$ These nondiscretionary and sensitive terms for earning discharge relief reflect further relaxation of fear of abuse at the most recent launch of a consumer insolvency system.

III. Consumer Discharge-in-Waiting: Fear of Abuse Manifest in Laws in Development

In countries that have not by this point followed the personal bankruptcy trend sweeping across Europe, one would expect to find a great deal of resistance to the notion of offering such relief. A resurgence of fear of abuse is fairly obvious in the last European straggler, Bulgaria, where proposed bills reflect this fear in objective, but all-but-insurmountable, barriers to relief. Beyond Europe, advanced-stage proposals developing in China and Saudi Arabia confirm that newcomers to personal discharge approach the policy conversation with great hesitancy.

\section{A. Bulgaria}

In 2000, household debt was hardly a blip on the social policy radar screen in Bulgaria. By 2008, household debt had exploded and while still not reaching the worrying levels of some other European states, had risen to and remained at a level that caught the attention of policymakers. ${ }^{127}$ Concerned

122. See KILBORN, supra note 29, at 34-35 (describing the increasing number of cases administered under France's "personal recovery" procedure for debtors whose financial situation is "irremediably compromised"); Jason J. Kilborn, Determinants of Failure ... and Success in Personal Debt Mediation, TRANSNAT’L DisP. MGMT. Nov. 2017 at 1, 11-12 (discussing the growth of France's bankruptcy commission regime).

123. Legii 151/2015 privind procedura insolvenței persoanelor fizice, supra note 117 , arts. 65 70.

124. Id. art. 57(1)(b).

125. Id. art. 3(25) (original in Romanian).

126. See id. art. 72 (prescribing the procedure for determining the duration of a debtor's payment period).

127. See Miroslav Nikolov, Households Indebtedness: State-of-the-Art, MONEY MATTERS, no. 14, 2017, at 7, 8 fig.3 (illustrating the sizeable growth in Bulgaria's household debt between 
Bulgarian legislators finally introduced a bill in February 2015 to provide "protection against overindebtedness of natural persons" in the form of a cost-free, European-style procedure of asset liquidation followed by a threeyear earned discharge period of relinquishment of nonexempt income. ${ }^{128}$ The explanatory note to the bill commented that " $[t]$ he public interest requires "eternal debtors' to be given an opportunity to engage anew in socially beneficial activity," consistent with European practice. ${ }^{129}$

This controversial bill made no progress before another was introduced on July 21, 2017. The tone and approach of this new bill are quite different from its predecessor's: debtors are deemed overindebted and allowed access to relief only if they have worked consistently during three of the preceding five years, their debts do not exceed 150,000 Bulgarian levs (about \$95,000), and they nonetheless appear unable to pay their debts with ten years of expected income. ${ }^{130}$ In such cases, the earned discharge period would be ten years on minimum income. ${ }^{131}$ Moreover, during this ten-year period, debtors are prohibited from entrepreneurial activity as members or directors of companies. ${ }^{132}$ Excluding retired people and long-term unemployed debtors and calling on ten years of earning capacity is sure to produce a remedy for very few maladies. One suspects Bulgaria is still some distance from a consumer discharge law of any kind, let alone an effective one. One can just picture the fear in legislators' eyes!

\section{B. China}

A most exciting recent development in China comes not from a central government project, but from a controlled provincial experiment. While China is in principle a highly centralized state, central authorities often afford significant autonomy to regional governments to pursue large-scale trial runs of new policies. Nowhere is this trend more powerful and more obvious than in the "special economic zones" developed during the period of "reform and opening" initiated by Deng Xiaoping in 1979. ${ }^{133}$ Deng's famous "southern

2000 and 2008); Bulgaria Household Debt 2000-2016, CEIC, https://www.ceicdata.com/en /indicator/bulgaria/household-debt [https://perma.cc/STW7-L7ZN] (reporting that Bulgaria's household debt "reached an all-time high" in December of 2008).

128. Proekt, Zakon za zashtita pri svrǔkhzadǔlzhenost na fizicheskite litsa [Draft, Law of Protection Against Overindebtedness of Natural Persons], 554-01-30 ot 12/02/2015, arts. 3(2), 6, 16, 26 (Bulg.).

129. Id., Notes at 12 (original in Bulgarian).

130. Bill, Zakon za zashtita pri svrǔkhzadŭlzhenost na fizicheskite litsa [Bill, Law of Protection Against Overindebtedness of Natural Persons], 754-01-46 ot 24/07/2017, arts. 4(1), 5 (Bulg.).

131. Id. art. 22(1), 30.

132. Id. art. 31.

133. Arthur R. Kroeber, ChinA's ECONOMY: WhAt Everyone NEEdS to KNOW 5 (2016). 
tour" in 1992 took him to one of the most prominent of these zones, Shenzhen, just to the north of Hong Kong. ${ }^{134}$

This hotbed of economic development and local initiative appears to be the likely future birthplace of personal bankruptcy law in China. In June 2014, a subgroup of the Shenzhen Bar Association began developing a personal bankruptcy bill for the Shenzhen Special Economic Zone. ${ }^{135}$ A draft law emerged by September 2015, with some unique and intriguing provisions that suggest Shenzhen authorities are stepping lightly into this new legal terrain. ${ }^{136}$

A preliminary review of the proposed law, working from this author's rather rudimentary foundation in Chinese, reveals what seem to be fairly rigorous and restrictive requirements for accessing the procedure and obtaining relief. To access the personal liquidation process, debtors must submit evidence of five years of income and expenditures (which presumably indicate their payment ability and substantiate their claimed inability to clear their debts timely), and their current standard of living must not exceed a level corresponding to the local minimum wage. ${ }^{137}$ The draft law seems to require the debtor to pay creditors the value of any nonexempt propertyincluding disposable income - the debtor reasonably anticipates receiving over the next two years, which must in any case suffice immediately to cover administrative costs. ${ }^{138}$

The discharge provision is a bit puzzling, but it seems to require a minimum distribution to creditors of at least the amount distributed to them by the debtor during the two-year period preceding the debtor's filing an application for liquidation; otherwise, a discharge is conferred only by the (extremely unlikely) unanimous vote of the creditors' committee. ${ }^{139}$ This

134. Id. at 7.

135. SHENZHEN JingJi TEQU GEREN Pochan TIAOLI CAO'AN JiANYi GaO Fu LiYou (深圳经 济特区个人破产条例草案建议稿附理由) [SHENZHEN SPECIAL ECONOMIC ZONE PERSONAL BANKRUPTCY REgUlation Draft PRoposal with ACCOMPANying REASONING] (Lu Lin

(卢林), ed., 2016) (China) [hereinafter Shenzhen Draft Bankruptcy Proposal]; see also "Shenzhen Jingji Tequ Geren Pochan Tiaoli” Dashiji (《深圳经济特区个人破产条例》大事记) [ “Shenzhen Special Economic Zone Personal Bankruptcy Ordinance” Retrospective], JiANGSU HUIJIN BANKR. LIQUIDATION FIRM LTD. (Mar. 3, 2016), http://www.js-hj.com/content/?190.html [https://perma.cc/MAC3-AMC7] [hereinafter JIANGSU HUIJIN] (China) (providing a timeline of the development of the Shenzhen bankruptcy proposal).

136. JIANGSU HUIJIN, supra note 135.

137. Shenzhen Draft Bankruptcy Proposal, supra note 135, arts. 95, 103.

138. Id. arts. 111, 113-16, 120.

139. Id . arts. 158-59. This unique discharge provision seems to be based on the discharge provision of the Taiwan Consumer Insolvency Act of 2008. Xiaofeizhe Zhaiwu Qingli Tiaoli

(消費者債務清理條例) [Consumer Debt Clean-Up Regulation] (amended Dec. 26, 2010), art. 133 (Taiwan, officially Republic of China), https://law.moj.gov.tw/LawClass/LawParaDeatil.aspx ?Pcode $=$ B0010042\&LCNOS $=++80+++\&$ LCC $=2$ [https://perma.cc/X5FR-ZEW9]. 
provision could spell trouble for any potential discharge procedure, and it suggests a deep fear of abuse by opportunistic debtors. Indeed, since 2013, the current nationwide approach to defaulting debtors in China has been a Supreme Court blacklist banning some debtors from using such "luxuries" as airplane and high-speed-train travel and hotels. ${ }^{140}$ Time will tell whether the Shenzhen draft or something like it becomes law and, if so, how it is applied by Chinese courts who seem to be both wholly unaccustomed to and quite skeptical of the concept of relief for defaulting debtors.

\section{Saudi Arabia}

The Saudi Ministry of Commerce and Industry delivered a bombshell when in April 2015 it released a policy paper on an initiative to revamp the Kingdom's insolvency law. ${ }^{141}$ That paper projected that a new procedure would encompass all private individuals, including ordinary consumers, and would offer an automatic discharge of unpaid liabilities following a liquidation and waiting period of twelve months. ${ }^{142}$ Another comment expectedly but ominously noted that "Shari' a compliance would be an important element when choosing public policies and the underlying rules." 143 This is ominous because no school of Islamic Law (shari'ah) seemed to support or even accept the notion of discharging debts without the consent of creditors. ${ }^{144}$ An imprint of the name of a Western law firm (Clifford Chance) on every page of the English portion of the policy paper offered reason for hope, however, so the announcement of a potential Islamic discharge was both confusing and exciting.

As it turned out, the Western law firm had apparently not sufficiently appreciated the implications of shari'ah compliance. The ultimate draft law released in September 2016 indeed adhered to Islamic Law and did not offer a nonconsensual discharge. ${ }^{145}$ The explanatory note to the new draft makes

140. See Yongxi Chen \& Anne Sy Cheung, The Transparent Self Under Big Data Profiling: Privacy and Chinese Legislation on the Social Credit System, 12 J. ComP. L., no. 2, 2017, at 356, 362, 370 (describing travel restrictions on judgment defaulters and public disclosures of public credit information); Yuan Yang, China Penalizes $6.7 \mathrm{~m}$ Debtors with Travel Ban, FIN. TIMES (Feb. 15, 2017) (reporting that a man surnamed Liu "almost lost his bride after the man's father ... was named on the local television as being blacklisted"), https://www.ft.com/content/ceb2a7f0f350-11e6-8758-6876151821a6 [https://perma.cc/FUF3-AQSU].

141. Ministry OF COMMERCE \& INDUS., THE KingDOM OF SAUdi ARABIA InSOlVENCY LAW PROJECT, POLICY PAPER (2016) (Saudi Arabia), http://mci.gov.sa/LawsRegulations/Projects/Pages /ippd.aspx\#1 [https://perma.cc/BV7Y-PQGH].

142. $I d . \S \S 4.1-4.5$.

143. Id. $\S 1.2(\mathrm{~b})($ iii).

144. Abed Awad \& Robert E. Michael, Iflas and Chapter 11: Classical Islamic Law and Modern Bankruptcy, 44 INT'L LAWYER 975, 981, 997, 999 (2010); Jason J. Kilborn, Foundations of Forgiveness in Islamic Bankruptcy Law: Sources, Methodology, Diversity, 85 AM. BANKR. L.J. 323,347 (2011).

145. Ministry of COMmerce \& Indus., Mashru' Nizam al-Iflaas [Draft of the System of 
no mention of the Western concept. The provisions on liquidation do apply to ordinary individuals, but the "rehabilitation" article is quite clear that following a liquidation of nonexempt assets, the debtor "is not discharged from his liability for remaining debt except for under a special or general discharge from creditors. ${ }^{\prime 146}$ In other words, perfectly consistent with Islamic Law, the new Saudi bankruptcy law offers individual debtors a discharge only with the consent of creditors, which one suspects is unlikely to be forthcoming. The current draft is reportedly on its way to becoming law in early 2018, ${ }^{147}$ leaving Saudi Arabia without consumer discharge. While adherence to Islamic Law may not be fairly equated with fear of abuse, there is a congruent reticence here to allow debtors to evade their obligations over creditor opposition - a reticence that appears likely to persist indefinitely in the Kingdom. ${ }^{148}$

\section{Conclusion}

Virtually none of the developments described here would have a counterpart in U.S. experience. Even the advent of the infamous means test for constraining access to quick chapter 7 relief is of a very different nature than the aggressive constraints on consumer discharge access witnessed in Europe over the past twenty years. Following these comparative developments (in English) has allowed policymakers and academics worldwide to explore more deeply and in greater detail the fear of abuse that Jay observed in the United States and Europe in the late 1990s, along with its gradual but definite abatement in recent years. Comparative analysis has greatly enriched the conversation about the proper balance of relief, restriction, and responsibility with the "rich harvest of new evidence" that Jay predicted. I am thrilled to have been part of that harvest and to say, once again, thanks, Jay!

Bankruptcy] (2016) (Saudi Arabia), http://mci.gov.sa/MediaCenter/elan/Documents/01.pdf [https://perma.cc/9E8P-KWSR].

146. Id. art. 160.

147. Saudi Arabia Advisory Council Approves Draft Bankruptcy Law, REUTERS (Dec. 13, 2017), http://www.reuters.com/article/saudi-bankruptcy/update-1-saudi-arabia-advisory-council -approves-draft-bankruptcy-law-idUSL8N1OD2IP [https://perma.cc/YF5A-8PYH].

148. The same is true elsewhere in the region, as the new United Arab Emirates bankruptcy law does not apply to nonmerchants at all, leaving overindebted consumers, particularly those who write NSF checks, still subject to arrest and imprisonment. See Qanun al'iiflas al-qanun al-aitihadaa raqm (9) lisanat 2016 [Bankruptcy Law] (Official Gazette 29 Sept. 2016, effective 29 Dec. 2016) (U.A.E.), https://www.mof.gov.ae/En/Lawsandpolitics/govlaws/pages/federalbankruptcy .aspx [https://perma.cc/M4KQ-A5DQ]; Issac John, Why UAE's New Bankruptcy Law Is a Boon for Business, KHALEEJ TIMES (Mar. 1, 2017), https://www.khaleejtimes.com/business/economy/uae -bankruptcy-law-boom-bust-bonanza [https://perma.cc/N64T-T98S]. 